\title{
Effects of manufacturing conditions on the adsorption capacity of heavy metal ions by Makino bamboo charcoal
}

\author{
Song-Yung Wang, Ming-Hsiu Tsai, Sheng-Fong Lo, Ming-Jer Tsai* \\ School of Forestry and Resource Conservation, College of Bio-Resource and Agriculture, National Taiwan University, No.1, Sec. 4, \\ Roosevelt Road, Taipei 10617, Taiwan, ROC
}

Received 17 September 2007; received in revised form 4 January 2008; accepted 5 January 2008

Available online 20 February 2008

\begin{abstract}
The objective of this study was to investigate the effects of manufacturing conditions on the adsorption capacity of heavy metal ions by Makino bamboo charcoal. Results show that the specific surface area and iodine number of bamboo charcoal activated at $900{ }^{\circ} \mathrm{C}$ were larger than those of bamboo charcoal activated at $800{ }^{\circ} \mathrm{C}$. The specific surface area of bamboo charcoal activated at $800{ }^{\circ} \mathrm{C}$ by carbon dioxide was larger than that of charcoal activated by steam. However, a contrary result was observed when the activation temperature was $900^{\circ} \mathrm{C}$.

The total volume and proportion of micropores in bamboo charcoal activated by carbon dioxide were greater than those in the other sample groups. However, the total volume and bulk volume of meso- and macropores, and average pore diameter for bamboo charcoal activated by steam were greater than those in the other sample groups.

Using $5 \mathrm{~g}$ bamboo charcoal (10-30 mesh) with a soaking time of $24 \mathrm{~h}$, a better adsorption effect on $\mathrm{Pb}^{2+}(100 \%), \mathrm{Cu}^{2+}(100 \%)$, and $\mathrm{Cr}^{3+}(88-98 \%)$ was found. However, medium frequencies were observed for the adsorption of $\mathrm{Cd}^{2+}(40-80 \%)$ and $\mathrm{Ni}^{2+}(20-60 \%)$. Very limited adsorption of $\mathrm{As}^{5+}$ was detected in this study.

For the same charcoal grain sizes, the adsorption capacity of $0.5 \mathrm{~g}$ of charcoal was better than that of $0.1 \mathrm{~g}$. The improved adsorption effect of the sample group activated by steam was compared with the sample group activated by carbon dioxide.
\end{abstract}

(c) 2008 Elsevier Ltd. All rights reserved.

Keywords: Makino bamboo charcoal; Activation; Adsorption capacity of heavy metal ions

\section{Introduction}

In the past, the heavy metal compounds in wastewater have been causing environmental pollution and serious symptoms of poisoning. Recently, this environmental damage has been monitored by modern technology. However, the environmental pollution still occurs because of problems of management of the liquid phase environment. Heavy metal pollution caused by lead, copper, chromium, cadmium, nickel and arsenic is most serious to the human body. Concentrations of $0.005 \mathrm{mg} / 1$ (for $\mathrm{Pb}^{2+}$ and $\mathrm{Cr}^{3+}$ ),

\footnotetext{
${ }^{*}$ Corresponding author. Tel.: +886 2 33664641; fax: +886223686335. E-mail address: tmj@ntu.edu.tw (M.-J. Tsai).
}

$0.001 \mathrm{mg} / 1$ (for $\mathrm{Cd}^{2+}, \mathrm{Ni}^{2+}$, and $\mathrm{As}^{5+}$ ) and $0.1 \mathrm{mg} / 1$ (for $\left.\mathrm{Cu}^{2+}\right)$, will cause humans to fall ill and can even be fatal (Kawarada et al., 2005). The removal of heavy metal ions is an important problem in the field of water purification.

Activated carbon is one of the materials being used to remove impurities from liquid solutions. It has been widely used to treat industrial and household water (Sirianuntapiboon and Ungkaprasatcha, 2007) because of its excellent adsorption properties, characterized by a high specific surface area (Cao et al., 2006). It is also used to remove metal ions from solution (Issabayeva et al., 2006). The increasing varieties and amounts of potentially hazardous impurities in water have led to increasing use of activated carbon. The problem associated with its use as a water purifier is largely economic; activated carbon is expensive. As this 
problem limits its use on a large industrial scale, more economical materials are needed. Although much work has been done on the use of activated carbon for water purification, heavy metal pollution is still a problem.

In order to reduce the cost of activated carbon, Pulido et al. (1998) have used carbonized sugi wood powder to remove mercury and other metal ions from aqueous solutions of their salts. They indicated that wood powder carbonized at $1000{ }^{\circ} \mathrm{C}$ achieved the best removal of heavy metal ions among the wood-based materials and was even better than commercial activated carbon in both single and mixed solutions.

In addition to plantation wood, bamboo is an important material due to its rapid growth and a shortage of timber in Taiwan. Makino bamboo is a multipurpose species grown in Taiwan for fuel wood, food (bamboo shoots), construction materials, handicrafts, mat boards, and pressboards and for several other uses. In order to develop an innovative processing system which can significantly increase the value of the utilization of bamboo, manufacturers have studied the use of Makino bamboo charcoal for the removal of impurities from liquid solutions. However, the influence of the manufacturing conditions on the adsorption capacity of heavy metal ions by Makino bamboo charcoal is still not well known. In the light of the above, the present study was carried out to investigate the effects of manufacturing conditions on the adsorption capacity for heavy metal ions (including $\mathrm{Pb}^{2+}, \mathrm{Cr}^{3+}, \mathrm{Cd}^{2+}, \mathrm{Ni}^{2+}$, $\mathrm{As}^{5+}$, and $\mathrm{Cu}^{2+}$ ) by Makino bamboo charcoal. The results can provide information for estimating the benefits of utilizing Makino bamboo in the manufacture of charcoal.

\section{Methods}

\subsection{Bamboo materials and manufacturing conditions of bamboo charcoal}

Four-year-old Makino bamboo (Phyllostachys makinoi Hayata) was selected for this study. These were sliced into strips $12 \mathrm{~cm}$ (length) $\times 2 \mathrm{~cm}$ (width) $\times 0.5-1.0 \mathrm{~cm}$ (thickness). Separate samples of Makino bamboo were carbonized in a nitrogen atmosphere at varying furnace temperatures between 800 and $900{ }^{\circ} \mathrm{C}$. Nitrogen gas was passed through the materials at a rate of $500 \mathrm{ml} / \mathrm{min}$ and heated at $10{ }^{\circ} \mathrm{C} / \mathrm{min}$. The temperature was kept at the target level for $2 \mathrm{~h}$, after which the heater and gas flow were turned off. The carbonized materials were allowed to cool naturally inside the furnace to room temperature. After cooling, the sample group GC-1 was re-carbonized with the above conditions and then activated by carbon dioxide; the sample groups $\mathrm{GH}-1$ and $\mathrm{GH}-4$ were activated by steam; the sample group GC-2 was activated by carbon dioxide; the sample group G-1 was without activation. The activation temperature was kept at 800 and $900{ }^{\circ} \mathrm{C}$ for $2 \mathrm{~h}$, respectively. The activated materials were allowed to cool naturally inside the furnace to room temperature before they were removed for analysis. The manufacturing conditions of Makino bamboo charcoal are shown in Table 1.

\subsection{Specific surface area measurement}

The specific surface area of the bamboo charcoal powder was measured using Micrometritics ASAP2010. The BET (Brunaeur-Emmet-Teller) multipoint method and Langmuir method were used to determine the surface area. Nitrogen $\left(\mathrm{N}_{2}\right)$ gas was used to determine the adsorption isotherms.

\subsection{Iodine number measurement}

The iodine number of the Makino bamboo charcoal was measured according to ASTM D4607-94 (1999): (1) Transfer $0.5 \mathrm{~g}$ Makino bamboo charcoal to a clean, dry $250-\mathrm{ml}$ Erlenmeyer flask equipped with a ground glass stopper. (2) Pipet $10 \mathrm{ml}$ of $5 \mathrm{wt} \%$ hydrochloric acid solution into each flask containing Makino bamboo charcoal. (3) Stopper each flask and swirl gently until the carbon is completely wetted. (4) Loosen the stoppers to vent the flasks, place on a hot plate in a fume hood, and bring the contents to a boil. Allow to boil gently for $30 \pm 2 \mathrm{~s}$ to remove any sulfur which may interfere with the test results. (5) Remove the flasks from the hot plate and cool to room temperature. (6) Pipet $100 \mathrm{ml}$ of $0.1 \mathrm{~N}$ iodine solution into each flask. Immediately stopper the flasks, and shake the contents vigorously for $30 \pm 1 \mathrm{~s}$. (7) Quickly filter each mixture by gravity through one sheet of folded filter paper (Whatman No. $2 \mathrm{~V}$ or equivalent) into a beaker. For each filtrate, use the first $20-30 \mathrm{ml}$ to rinse a pipet. Discard the rinse portions. Use clean beakers to collect the remaining filtrates. (8) Mix each filtrate by swirling the beaker and pipet $50 \mathrm{ml}$ of each filtrate into a clean 250-ml Erlenmeyer flask. (9) Titrate each filtrate with standardized $0.1 \mathrm{~N}$ sodium

Table 1

Manufacturing conditions of Makino bamboo charcoal

\begin{tabular}{|c|c|c|c|c|c|c|}
\hline Sample group ${ }^{a}$ & Carbonization times & $\begin{array}{l}\text { Highest carbonization } \\
\text { temperature }\left({ }^{\circ} \mathrm{C}\right)\end{array}$ & Activator & $\begin{array}{l}\text { Activator } \\
\text { injection rate }\end{array}$ & $\begin{array}{l}\text { Activation } \\
\text { temperature }\left({ }^{\circ} \mathrm{C}\right)\end{array}$ & $\begin{array}{l}\text { Activation } \\
\text { time }(\mathrm{h})\end{array}$ \\
\hline GH-1 & 1 & 800 & $\mathrm{H}_{2} \mathrm{O}$ & $400(\mathrm{ml} / \mathrm{h})$ & 800 & 2 \\
\hline GC-1 & 2 & 800 & $\mathrm{CO}_{2}$ & $400(\mathrm{ml} / \mathrm{min})$ & 800 & 2 \\
\hline G-1 & 1 & 900 & - & - & - & - \\
\hline GH-4 & 1 & 900 & $\mathrm{H}_{2} \mathrm{O}$ & $400(\mathrm{ml} / \mathrm{h})$ & 900 & 2 \\
\hline GC-2 & 1 & 900 & $\mathrm{CO}_{2}$ & $400(\mathrm{ml} / \mathrm{min})$ & 900 & 2 \\
\hline
\end{tabular}

a The pH values of GH-1, GC-1, G-1, GH-4, and GC-2 solutions (according to ASTM D3838-80) are 8.96, 9.23, 10.16, 9.12, and 9.40, respectively. 
thiosulfate solution until the solution is a pale yellow. Add $2 \mathrm{ml}$ of the starch indicator solution and continue the titration with sodium thiosulfate until one drop produces a colorless solution. (10) Record the volume of sodium thiosulfate used for determination of the amount of iodine adsorbed on to the carbon $(\mathrm{mg} / \mathrm{g})$.

\subsection{Adsorption experiment}

Standard solutions of lead nitrate $\left[\mathrm{Pb}\left(\mathrm{NO}_{3}\right)_{2}\right]$, copper nitrate $\left[\mathrm{Cu}\left(\mathrm{NO}_{3}\right)_{2}\right]$, nickel nitrate $\left[\mathrm{Ni}\left(\mathrm{NO}_{3}\right)_{2}\right]$, chromium nitrate $\left[\mathrm{Cr}\left(\mathrm{NO}_{3}\right)_{3}\right]$, cadmium nitrate $\left[\mathrm{Cd}\left(\mathrm{NO}_{3}\right)_{2}\right]$, and arsenic acid $\left[\mathrm{H}_{3} \mathrm{AsO}_{4}\right]$ in distilled water were prepared at $10 \mathrm{ppm}$ concentrations on the basis of weight by weight $(\mathrm{w} / \mathrm{w})$ of each metal molecule. The $\mathrm{pH}$ values of lead nitrate, copper nitrate, nickel nitrate, chromium nitrate, cadmium nitrate, and arsenic acid solutions are 2.10, $2.08,1.98,2.09,2.13$, and 2.10, respectively. The charcoals from various manufacturing conditions were first placed in a 250-ml Erlenmeyer flask. Twenty milliliter of a standard heavy metal solution with a concentration of $10 \mathrm{ppm}$ was added to the flask. The mixtures were stirred continuously in a constant temperature-controlled bath at $20^{\circ} \mathrm{C}$ and left to settle before samples were taken after $1,2,4,8,12,24$, and $48 \mathrm{~h}$ (soaking time), respectively. The concentrations of heavy metal ions in the samples were measured using the ICP-AES (Inductively Coupled Plasma-Atomic Emission Spectroscopy; SPECTRO GENESIS, Germany).

\section{Results and discussion}

\subsection{Effects of manufacturing conditions on the specific surface area and iodine number}

Results for the carbon yield, specific surface area, and iodine number of various Makino bamboo charcoals are listed in Table 2. A low carbon yield (12.3\%) was found for the sample group GH-4, whereas high carbon yields $(25.2-25.8 \%)$ were measured for sample groups GH-1 and G-1. However, a high specific surface area was observed for the sample group GH-4, and low specific surface areas for sample groups GH-1 and G-1. Kitamura and Katayama (2001) indicated that the specific surface area of charcoal increased with an increasing pore structure during the oxidation process. The specific surface area of the sample groups (GH-4 and GC-2) with an activation tempera-

Table 2

Carbon yield, specific surface area and iodine number of various Makino bamboo charcoals

\begin{tabular}{lllcl}
\hline $\begin{array}{l}\text { Sample } \\
\text { group }\end{array}$ & $\begin{array}{l}\text { Carbon } \\
\text { yield }(\%)\end{array}$ & \multicolumn{2}{l}{ Specific surface area $\left(\mathrm{m}^{2} / \mathrm{g}\right)$} & $\begin{array}{l}\text { Iodine number } \\
(\mathrm{mg} / \mathrm{g})\end{array}$ \\
\cline { 3 - 4 } & & BET method & Langmuir method & \\
\hline GH-1 & 25.2 & 473.9 & 628.6 & 498.8 \\
GC-1 & 21.6 & 570.0 & 755.3 & 571.0 \\
G-1 & 25.8 & 563.6 & 747.4 & 480.5 \\
GH-4 & 12.3 & 794.1 & 1073.1 & 689.6 \\
GC-2 & 22.6 & 594.3 & 787.3 & 538.9 \\
\hline
\end{tabular}

ture of $900{ }^{\circ} \mathrm{C}$ was larger than that of sample groups (GH-1 and GC-1) with an activation temperature of $800{ }^{\circ} \mathrm{C}$. This may be because high temperature results in easy formation of holes (Teng et al., 1998; Wu et al., 1999). Kitamura and Katayama (2001) also revealed that the specific surface area increased with increasing temperature. However, the specific surface area decreased rapidly when the temperature was over $1100^{\circ} \mathrm{C}$. This resulted in shrinkage of the carbon with collapse, and dispersal of the pore structure and a tendency to reconfiguration as a graphite structure (Ishihara, 1999; Kitamura et al., 2002; Wang, 2004).

Compared to bamboo charcoal activated by carbon dioxide (GC-2), bamboo charcoal activated by steam (GH-4) had a larger specific surface area. In general, the activation reaction was carried out above $750^{\circ} \mathrm{C}$ by steam and above $850{ }^{\circ} \mathrm{C}$ by carbon dioxide (Liu, 1998). In this study, the highest carbonization temperature for sample groups GC-2 and GH-4 was $900{ }^{\circ} \mathrm{C}$ for $2 \mathrm{~h}$. Possibly the sample group GH-4 has the most generous time for activation.

As shown in Table 2, the iodine number or specific surface area measured by the BET method increased with decreasing carbon yield. Table 2 also shows a high correlation between the iodine number and the specific surface area as measured by the BET method. The following linear regression equation was obtained using an $F$-value test:

Iodine number $($ by ASTM D-4607-94) $=0.6366 \times$ specific surface area $+174.34, R^{2}=0.83$.

\subsection{Pore diameter, volume quantity and proportion of different pore diameters}

The frequency of pore diameters can be used as an indicator of adsorption capacity in an activated carbon material. The sample groups GH-4 and GC-2 were chosen for pore diameter investigations by the BJH method (Barrett et al., 1951). Values for the volume quantity and proportion of different pore diameters, calculated by the $\mathrm{BJH}$ method, are shown in Table 3. The volume quantity and proportion of micropores for sample group GC-2 (activated by carbon dioxide) were larger than those for sample group GH-4 (activated by steam). However, the volume quantity and proportion of meso- and macropores, the bulk volume and the average pore diameter were greater for sample group GH-4. As shown in Table 2, the specific surface area (from the BET method) of GH-4 and GC-2 were $794 \mathrm{~m}^{2} / \mathrm{g}$ and $594 \mathrm{~m}^{2} / \mathrm{g}$, respectively. There is a high frequency of micropores in GH-4 and GC-2. However, the frequency of mesopores was higher in $\mathrm{GH}-4$ than in GC-2.

Wu et al. (1999) investigated the distribution of pore diameters from bamboo charcoal (Phyllostachys bambusoides) activated at $850{ }^{\circ} \mathrm{C}$ for $2 \mathrm{~h}$. It was found that the largest and average pore diameter were around $3.8 \mathrm{~nm}$ and $2.63 \mathrm{~nm}$, respectively. There are high frequencies of microand mesopores. Daud and Ali (2004) also reported a high 
Table 3

The volume quantity and proportion of different pore diameters of Makino bamboo charcoals

\begin{tabular}{|c|c|c|c|c|c|c|c|}
\hline \multirow[t]{3}{*}{ Sample group } & \multirow{2}{*}{\multicolumn{2}{|c|}{$\begin{array}{l}\text { Volume quantity }\left(\times 10^{-3} \mathrm{~cm}^{3} / \mathrm{g}\right) \\
\text { Pore diameter }\end{array}$}} & \multirow{3}{*}{$\begin{array}{l}\text { Bulk volume } \\
\left(\times 10^{-3} \mathrm{~cm}^{3} / \mathrm{g}\right)\end{array}$} & \multirow{3}{*}{$\begin{array}{l}\text { Average pore } \\
\text { diameter }(\mathrm{nm})\end{array}$} & \multicolumn{3}{|c|}{ Proportion of pore diameter $(\%)$} \\
\hline & & & & & \multicolumn{3}{|c|}{ Pore diameter } \\
\hline & $\begin{array}{l}\text { Micropore } \\
(<2 \mathrm{~nm})\end{array}$ & $\begin{array}{l}\text { Meso- and } \\
\text { macropore }(>2 \mathrm{~nm})\end{array}$ & & & $\begin{array}{l}\text { Micropore } \\
(<2 \mathrm{~nm})\end{array}$ & $\begin{array}{l}\text { Mesopore } \\
(2-50 \mathrm{~nm})\end{array}$ & $\begin{array}{l}\text { Macropore } \\
(>50 \mathrm{~nm})\end{array}$ \\
\hline GH-4 & 249.87 & 55.87 & 305.74 & 1.99 & 90.20 & 9.79 & 0.01 \\
\hline GC-2 & 258.03 & 28.87 & 286.90 & 1.92 & 92.24 & 7.75 & 0.01 \\
\hline
\end{tabular}

frequency of micropores in activated carbons from palm shell and coconut shell using an activation temperature of $850{ }^{\circ} \mathrm{C}$. Furthermore, the volume quantity of macropores increased significantly at an activation temperature of $600{ }^{\circ} \mathrm{C}$. However, the increased frequency of mesopores was not evident. In addition, micro- and mesopores increased along with a decrease of the carbon yield when the activation temperature was $800^{\circ} \mathrm{C}$ and the activator was carbon dioxide. In comparison to the charcoal activated by steam, the frequency of micro- and mesopores was higher, whereas the frequency of meso- and macropores was lower. The volume quantity of meso- and macropores increased significantly with increasing activation temperature $\left(750-800^{\circ} \mathrm{C}\right)$, when steam was used as an activator. Compared to commercial activated carbon with a pore diameter of $1.7-2.9 \mathrm{~nm}$ and with a specific surface area of $650-1200 \mathrm{~m}^{2} / \mathrm{g}$ as used for the purification of wastewater (Wu et al., 1999), the Makino bamboo charcoal manufactured in this study can meet this standard.

\subsection{Effects of soaking time on adsorption capacity of heavy metal ions}

The results indicate that Makino bamboo charcoal activated by steam (GH-4: 0.1 g, 60-100 mesh) with a soaking time of $24 \mathrm{~h}$ had better adsorption capacity for $\mathrm{Pb}^{2+}$ $(2.9 \mathrm{ppm})$ and $\mathrm{Cu}^{2+}(1.7 \mathrm{ppm})$, but poorer adsorption capacities were found for $\mathrm{Cr}^{3+}(0.7 \mathrm{ppm}$ with a soaking time of $12 \mathrm{~h}), \mathrm{Ni}^{2+}(0.7 \mathrm{ppm}$ with a soaking time of $24 \mathrm{~h})$, $\mathrm{Cd}^{2+}(0.2 \mathrm{ppm}$ with a soaking time of $48 \mathrm{~h})$, and $\mathrm{As}^{5+}$ ( $0.05 \mathrm{ppm}$ with a soaking time of $24 \mathrm{~h})$. Fig. 1 shows no evi-

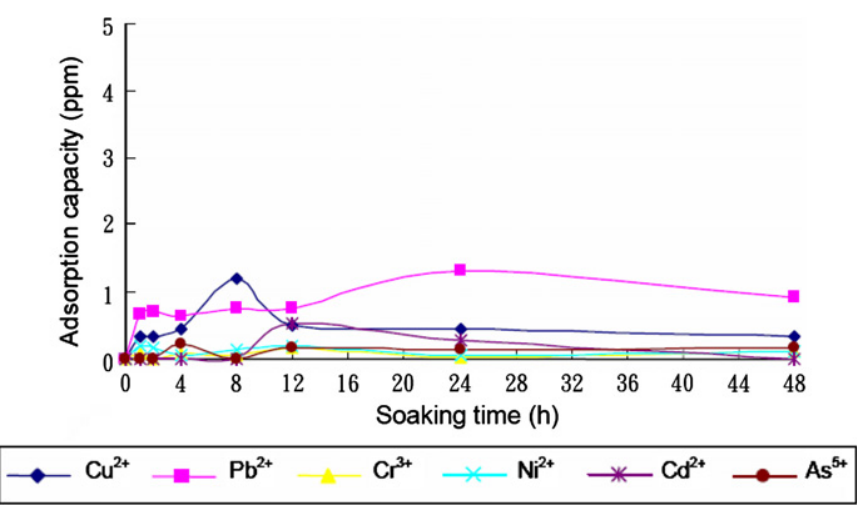

Fig. 1. Relationship between the soaking time and the metal ion adsorption capacity of Makino bamboo charcoal (GC-2: $0.1 \mathrm{~g}, 60$ 100 mesh) activated by carbon dioxide. dence for any effect of soaking time on the heavy metal ion adsorption capacity of Makino bamboo charcoal (GC-2: $0.1 \mathrm{~g}, 60-100 \mathrm{mesh})$ activated by carbon dioxide. Our results reveal that the sample group GC-2 had better adsorption capacities for $\mathrm{Pb}^{2+}$ and $\mathrm{Cu}^{2+}$, but values were lower than those for the sample group GH-4. Furthermore, lower adsorption capacities for $\mathrm{Cr}^{3+}, \mathrm{Ni}^{2+}, \mathrm{Cd}^{2+}$, and $\mathrm{As}^{5+}$ were also found in this study.

The results also indicate that the $\mathrm{Ni}^{2+}$ adsorption capacities of the sample groups GH-4 (0.5 g, 10-30 mesh) and GC-2 (0.5 g, 10-30 mesh) increased with increasing soaking time. The adsorption capacities of $\mathrm{Ni}^{2+}$ with a soaking time of $24 \mathrm{~h}$ were $7.0 \mathrm{ppm}$ and $3.2 \mathrm{ppm}$ for the sample groups GH-4 and GC-2, respectively.

The adsorption process of heavy metal ions by charcoal includes external diffusion, internal diffusion and adsorption. The metal ion adsorption speed is mainly influenced by external diffusion and internal diffusion (Weber et al., 1991). The adsorption forces of the hydrophobic surface of bamboo charcoal are larger when the charcoal pit size is closer to the size of the heavy metal cation (Abe et al., 2001). However, compared to chemical adsorption forces, the adsorption forces of the hydrophobic surface of bamboo charcoal are weaker. It is possible that the adsorbed heavy metal ions will be desorbed (Lo, 2001).

In this study, a small quantity of charcoal $(0.1 \mathrm{~g})$ and a high concentration heavy metal ions $(10 \mathrm{ppm})$ were tested. The adsorption process ceased after a relatively short duration. In this procedure, the sample group GH-4 with the larger specific surface area was able to adsorb more heavy metal ions with no soaking time influence. However, the desorption of adsorbed heavy metal ions can occur with the sample group GC-2 during the soaking process because of its smaller specific surface area. The results reveal that the $\mathrm{Ni}^{2+}$ adsorption capacities shown in tests with $0.5 \mathrm{~g}$ of charcoal were better than those with $0.1 \mathrm{~g}$. The $0.5 \mathrm{~g}$ sample of charcoal had a larger specific surface area than the $0.1 \mathrm{~g}$ sample. The adsorption capacities of $\mathrm{Ni}^{2+}$ increased with increasing soaking time. This evidence of an increased rate of adsorption capacity of charcoal was observed with soaking time of up to $4 \mathrm{~h}$.

\subsection{Effects of manufacturing conditions on the adsorption capacity of heavy metal ions}

Fig. 2 reveals the effects of manufacturing conditions on the charcoal's adsorption capacity for heavy metal ions 


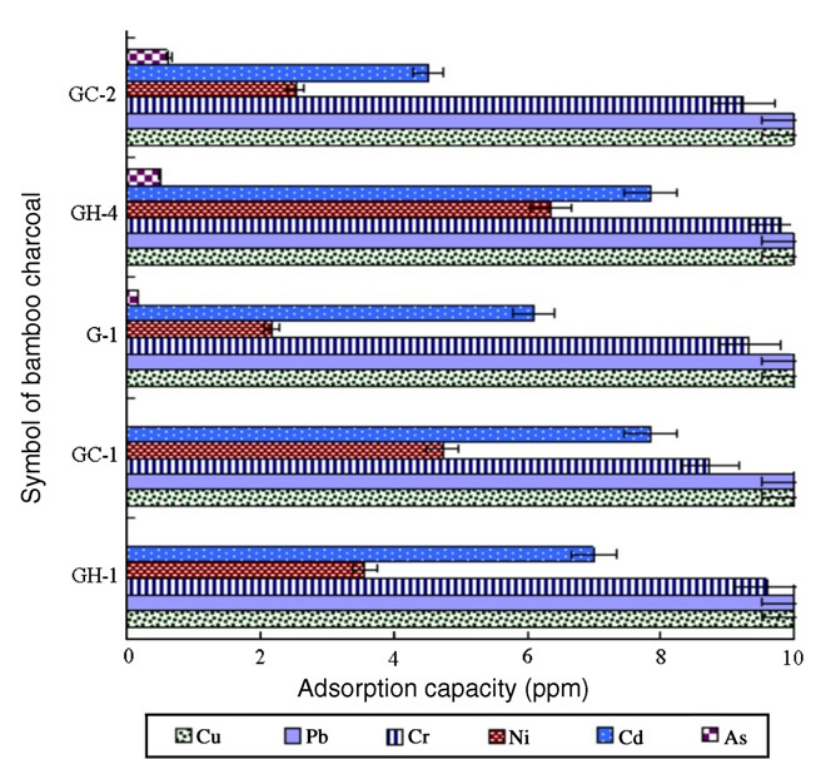

Fig. 2. Effect of manufacturing conditions on the adsorption capacity of heavy metal ions by Makino bamboo charcoal.

(10 ppm). $0.5 \mathrm{~g}$ of bamboo charcoal (10-30 mesh) with a soaking time of $2 \mathrm{~h}$ was examined. Results reveal that all the tested sample groups had better adsorption capacities for $\mathrm{Pb}^{2+}(10 \mathrm{ppm}), \mathrm{Cu}^{2+}(10 \mathrm{ppm})$, and $\mathrm{Cr}^{3+}(8.8-$ $9.8 \mathrm{ppm})$. Fig. 2 also demonstrates that the $\mathrm{Ni}^{2+}$ adsorption capacities of tested materials carbonized at $800{ }^{\circ} \mathrm{C}$ increased with increasing specific surface area. Furthermore, the $\mathrm{Ni}^{2+}$ adsorption capacities of tested materials carbonized at $900{ }^{\circ} \mathrm{C}$ and activated by steam or carbon dioxide increased linearly with increasing specific surface area $\left(R^{2}=0.989\right)$. Moreover, the sample groups $\mathrm{GH}-1$, GC-1, and GH-4 showed better adsorption capacities for $\mathrm{Cd}^{2+}$ than the other sample groups. However, the $R^{2}$ value was low. For all tested bamboo charcoals, no significant effect on the adsorption capacity for $\mathrm{As}^{5+}$ was observed. In particular, the sample groups GH-1 and GC-1 did not show any effect at manufacturing temperatures of $800^{\circ} \mathrm{C}$.

Lo (2001) reported that the $\mathrm{Pb}^{2+}$ adsorption capacity of charcoal was mainly affected by the functional groups on the charcoal surface. The carboxylic groups on adsorbents can play an important role in the adsorption of $\mathrm{Cu}^{2+}, \mathrm{Pb}^{2+}$, and $\mathrm{Ni}^{2+}$ (Kadirvelu et al., 2000). Many researchers also reported the positive influence of acid functional groups and surface oxidation on the adsorption capacity for heavy metal ions (Pendyal et al., 1999; Ahmendna et al., 2000; Dong et al., 2000; Manju et al., 2002; Rangel-Mendez and Streat, 2002; Machida et al., 2005). Wang (2004) indicated that $\mathrm{K}, \mathrm{Ca}, \mathrm{Mg}, \mathrm{Fe}, \mathrm{Mn}, \mathrm{Si}$, and $\mathrm{Cl}$ can be found on the bamboo charcoal surface. After surface oxidation, they may form metal oxide compounds, which contribute to the adsorption of heavy metal ions. Bamboo charcoal, with larger specific surface area, more functional groups and metal oxide compounds had better adsorption capacity for $\mathrm{Pb}^{2+}, \mathrm{Cu}^{2+}, \mathrm{Cd}^{2+}$, and $\mathrm{Ni}^{2+}$.

\subsection{Effects of charcoal grain sizes and quantity on adsorption capacity of heavy metal ions}

Fig. 3 indicates the effects of charcoal grain size on the adsorption capacity for heavy metal ions $(10 \mathrm{ppm}) .0 .5 \mathrm{~g}$ of bamboo charcoal (GH-4, GC-2: 10-30 mesh and 60100 mesh) with a soaking time of $24 \mathrm{~h}$ was investigated. Results show that the tested sample groups had better adsorption capacities for $\mathrm{Pb}^{2+}(10 \mathrm{ppm}), \mathrm{Cu}^{2+}(10 \mathrm{ppm})$, and $\mathrm{Cr}^{3+}(10 \mathrm{ppm})$. The sample groups tested also had greater adsorption capacity for $\mathrm{Cd}^{2+}$ (about $9 \mathrm{ppm}$ ). In this case no significant effect of charcoal grain size on adsorption capacity was observed. Smaller grain sizes showed better effects than larger grain sizes for all tested charcoals. Machida et al. (2005) reported that the specific surface area of charcoal and its adsorption capacity increased with decreasing grain size. In addition, the gap area of charcoal for adsorption of heavy metal ions increased because of small charcoal grain sizes (Liang and Lin, 1999). In this study, the sample group GH-4 (activated by steam) had a good adsorption capacity because of its large volume quantity, whereas the sample group GC-2 (activated by carbon dioxide) had a good adsorption capacity because of its high frequency of micropores.

The diameters of $\mathrm{Pb}^{2+}, \mathrm{Cu}^{2+}, \mathrm{Cr}^{3+}, \mathrm{Ni}^{2+}, \mathrm{Cd}^{2+}$, and $\mathrm{As}^{5+}$ are $0.0940 \mathrm{~nm}, 0.0620 \mathrm{~nm}, 0.0615 \mathrm{~nm}, 0.0690 \mathrm{~nm}$, $0.0800 \mathrm{~nm}$, and $0.0500 \mathrm{~nm}$, respectively (Lin, 1993). They are smaller than those of sample groups GH-4 (1.99 nm) and GC-2 (1.92 nm) (Table 3). As a result, desorption of heavy metal ions was not commonly observed during the adsorption process (Abe et al., 2001). The adsorption capacity was influenced by the diameter of the heavy metal cation and the distribution of charcoal pore diameters. Kadirvelu et al. (2000) reported that $\mathrm{Pb}^{2+}$ was highly

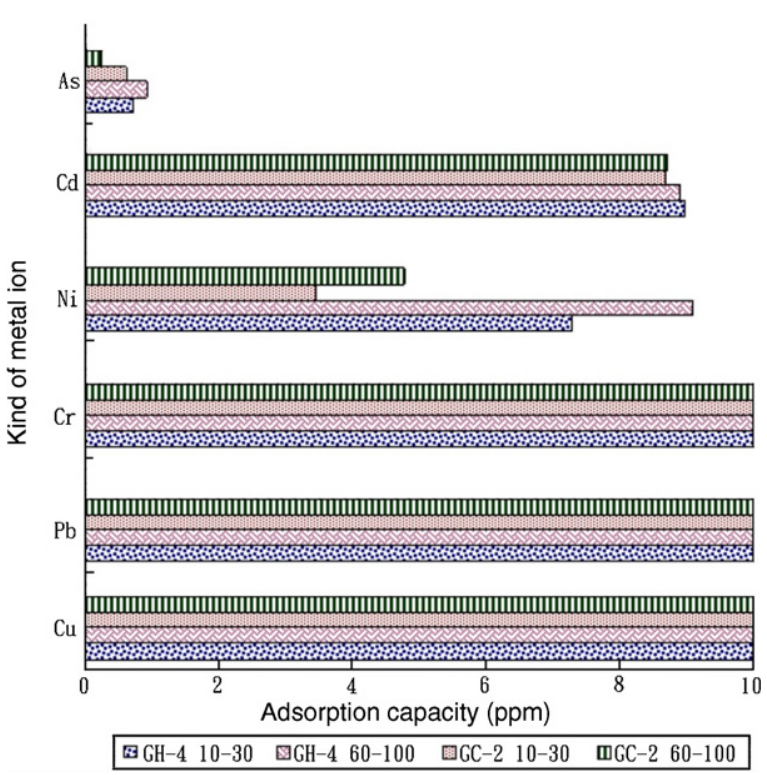

Fig. 3. Effect of grain size of the Makino bamboo charcoal (GH-4 and GC-2) on the metal ion adsorption capacity. 


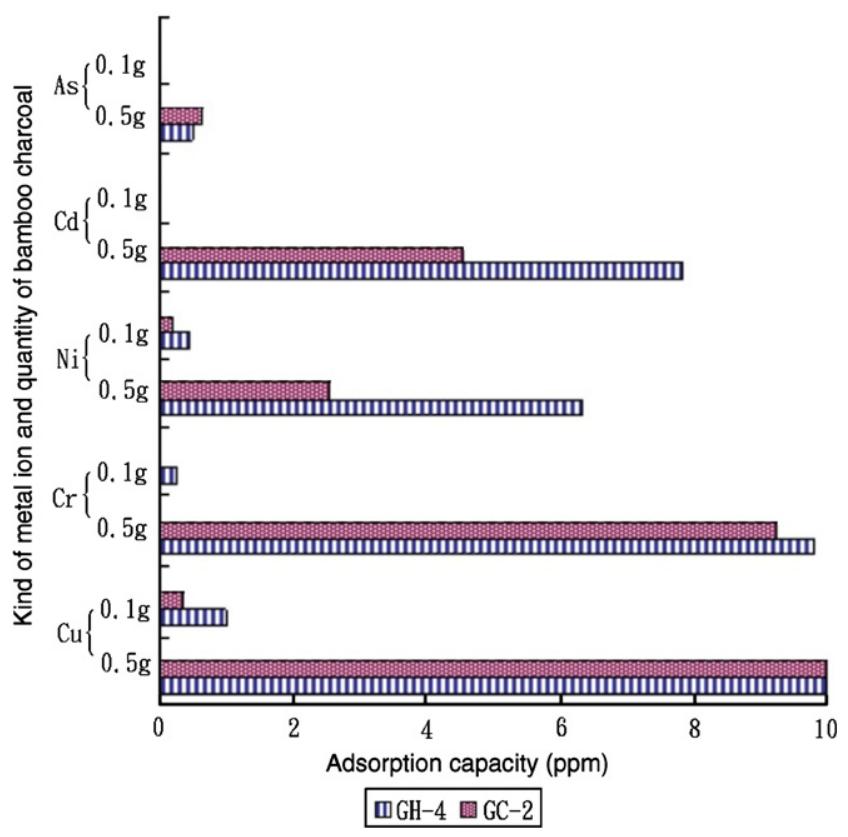

Fig. 4. Effect of different manufacturing conditions (GH-4 and GC-2) and Makino bamboo charcoal quantities $(0.1 \mathrm{~g}$ and $0.5 \mathrm{~g})$ on the adsorption capacity of heavy metal ions.

adsorbed by mesopore charcoal. In this study, the percentages of mesopores in sample groups GH-4 and GC-2 were $75.87 \%$ and $68.36 \%$, respectively.

It was also found that the $\mathrm{Pb}^{2+}$ adsorption capacity by Makino bamboo charcoal (GH-4) increased with increase of charcoal quantity and reached maximum adsorption capacity with $0.3 \mathrm{~g}$ of charcoal.

Fig. 4 demonstrates the effect of different manufacturing conditions (GH-4 and GC-2) and charcoal quantities $(0.1 \mathrm{~g}$ and $0.5 \mathrm{~g}$ ) on the adsorption capacity for heavy metal ions. Compared to $0.1 \mathrm{~g}$ of bamboo charcoal, the heavy metal ion adsorption capacity of $0.5 \mathrm{~g}$ of bamboo charcoal was more than five times better.

\section{Conclusions}

The effects of manufacturing conditions on the adsorption capacity of heavy metal ions using Makino bamboo charcoal were investigated in this study. Our results show that the specific surface area and iodine number of bamboo charcoal activated at $900{ }^{\circ} \mathrm{C}(\mathrm{GH}-4$ and GC-2) were greater than those of bamboo charcoal activated at $800{ }^{\circ} \mathrm{C}(\mathrm{GH}-1$ and GC-1). In comparison to bamboo charcoal activated at $800{ }^{\circ} \mathrm{C}$ by carbon dioxide (GC-1), the specific surface area was larger than that of charcoal activated by steam $(\mathrm{GH}-$ 1). However, a contrary result was observed when the activation temperature was $900^{\circ} \mathrm{C}$.

The volume quantity and proportion of micropores in bamboo charcoal activated by carbon dioxide (GC-1 and GC-2) were greater than those of the other sample groups. However, the volume quantity and bulk volume of mesoand macropores, and average pore diameter for the Maki- no bamboo charcoal activated by steam (GH-1 and GH-4) were greater than those in the other sample groups.

Using $5 \mathrm{~g}$ bamboo charcoal (10-30 mesh) with a soaking time of $24 \mathrm{~h}$, a better adsorption effect was found for $\mathrm{Pb}^{2+}$ $(100 \%), \mathrm{Cu}^{2+}(100 \%)$, and $\mathrm{Cr}^{3+}(88-98 \%)$. However, medium frequencies were observed for the adsorption effect on $\mathrm{Cd}^{2+}(40-80 \%)$ and $\mathrm{Ni}^{2+}(20-60 \%)$. The average $\mathrm{Cd}^{2+}$ and $\mathrm{Ni}^{2+}$ adsorption capacities of various charcoal groups were (in decreasing order) GH-4 $>$ GC-1 $>$ GH-1 $>$ GC-2 $>$ G1 , and GH-4 $>$ GC-1 $>$ GH-1 $>$ G-1 $>$ GC-2, respectively. For the adsorption of $\mathrm{As}^{5+}$, only the sample groups GC2, GH-1 and G-1 had any effect and this was very limited.

Our results indicate that the sample group GC-2 had better adsorption capacity for $\mathrm{Pb}^{2+}$ and $\mathrm{Cu}^{2+}$, but values were lower than those of sample group GH-4. Furthermore, smaller adsorption capacities for $\mathrm{Cr}^{3+}, \mathrm{Ni}^{2+}, \mathrm{Cd}^{2+}$, and $\mathrm{As}^{5+}$ were also detected in this study. For the same grain sizes, the adsorption capacities of $0.5 \mathrm{~g}$ charcoal were better than those for $0.1 \mathrm{~g}$. Better adsorption by the sample group activated by steam was observed in comparison to the sample group activated by carbon dioxide.

\section{Acknowledgements}

The authors wish to thank the Forestry Bureau, Council of Agriculture, Executive Yuan, Taiwan, ROC for financial support under grant 96AS-7.2.2-FB-e2.

\section{References}

Abe, I., Fukuhara, T., Maruyama, J., Tatsumota, H., Iwasaki, S., 2001. Preparation of carbonaceous adsorbents for removal of chloroform from drinking water. Carbon 39, 1069-1073.

Ahmendna, M., Marshall, W.E., Rao, R.M., 2000. Production of granular activated carbon from select and agricultural by-products and evaluation of their physical chemical and adsorption properties. Bioresource Technology 71, 113-123.

American Society for Testing and Materials (ASTM), 1999. D3838-80 Standard test method for $\mathrm{pH}$ of activated carbon.

American Society for Testing and Materials (ASTM), 1999. D-4607-94 (Reapproved). Standard test method for determination of iodine number of activated carbon.

Barrett, E.P., Joyner, L.E., Halenda, P.P., 1951. The determination of pore volume and area distribution in porous substance. I. Computation from nitrogen isotherms. Journal of the American Chemical Society 73 (1), 373-380.

Cao, Q., Xie, K.C., Lv, Y.K., Bao, W.R., 2006. Process effects on activated carbon with large specific surface area from corn cob. Bioresource Technology 97 (1), 110-115.

Daud, W.M.A.W., Ali, W.S.W., 2004. Comparison on pore development of activated carbon produced from palm shell and coconut shell. Bioresource Technology 93 (1), 63-69.

Dong, D., Nelson, Y.M., Lion, L.W., Shuler, M.L., Ghiorse, W.C., 2000. Adsorption of $\mathrm{Pb}$ and $\mathrm{Cd}$ onto metal oxides and orgasmic material in natural surface coatings as determined by selective extractions: new evidence for the importance of Mn and Fe oxides. Water Research 34, $427-436$.

Ishihara, S., 1999. Wood charcoal as functional carbon materials. Journal of the Society of Materials Science Japan 48 (5), 473-483.

Issabayeva, G., Aroua, M.K., Sulaiman, N.M.N., 2006. Removal of lead from aqueous solutions on palm shell activated carbon. Bioresource Technology 97 (18), 2350-2355. 
Kadirvelu, K., Faur-Brasqnet, C., Le Cloirec, P., 2000. Removal of $\mathrm{Cu}(\mathrm{II}), \mathrm{Pb}(\mathrm{II})$ and $\mathrm{Ni}(\mathrm{II})$ by adsorption onto activated carbon cloths. Langmuir 16, 8404-8409.

Kawarada, K., Haneishi, K., Iida, T., 2005. Pore structure and performance for drinking water treatment of activated carbon prepared from sugi thinning from water source forest in Tokyo. Wood Industry 60 (12), 398-401.

Kitamura, T., Katayama, H., 2001. The effect of carbonizing conditions on the specific surface area of charcoal from sugi (Cryptomeria japonica) wood. Mokuzai Gakkaishi 47 (2), 164-170.

Kitamura, T., Taguchi, T., Katayama, H., 2002. The effects of carbonizing conditions on the specific surface area of charcoal from sugi (Cryptomeria japonica) wood II: the effects of carbonizing temperature and carbon dioxide concentration in carbonizing atmospheres. Mokuzai Gakkaishi 48 (4), 272-279.

Liang, J.Y., Lin, H.C., 1999. Removal of $\mathrm{Cd}, \mathrm{Ni}, \mathrm{Pb}$ and $\mathrm{Zn}$ from solution by agricultural waste. Journal of the Chinese Agricultural Chemical Society Engineering 37 (3), 412-419.

Lin, C.E., 1993. Chemistry Dictionary. Ho-Chi Book Publishing Co., Taipei, p. 94.

Liu, T.S., 1998. Manufacturing technology and application of activated carbons. Industry Investigation and Technology 127, 84-97.

Lo, C.C., 2001. Characteristic study of VOCs in the surrounding area of an oil storage and pumping station. A thesis of master degree of the Graduate Institute of Environmental Engineering, National Sun YatSen University, pp. 36-39.

Machida, M., Yanazaki, R., Aikawa, M., Tatsumoto, H., 2005. Role of minerals in carbonaceous adsorbents for removal of $\mathrm{Pb}$ (II) ions from aqueous solution. Separation and Purification Technology 46, 88-94.

Manju, G.N., Krishnan, K.A., Vinod, V.P., Anirudhan, T.S., 2002. An investigation into the sorption of heavy metals from wastewaters by polyacrylamide-grafted iron (III) oxide. Journal of Hazardous Materials B 91, 221-238.

Pendyal, B.M., Johns, M., Marshall, W.E., Ahmenda, M., Rao, R.M., 1999. The effect of binders and agricultural by products on physical and chemical properties of granular activated carbons. Bioresource Technology 68, 247-254.

Pulido, L.L., Hata, T., Imamura, Y., Ishihara, S., Kajimoto, T., 1998. Removal of mercury and other metals by carbonized wood powder from aqueous solutions of their salts. Journal of Wood Science 44, 237-243.

Rangel-Mendez, J.R., Streat, M., 2002. Adsorption of cadmium by activated carbon cloth: influence of surface oxidation and solution $\mathrm{pH}$. Water Research 36, 1244-1252.

Sirianuntapiboon, S., Ungkaprasatcha, O., 2007. Removal of $\mathrm{Pb}^{2+}$ and $\mathrm{Ni}^{2+}$ by bio-sludge in sequencing batch reactor (SBR) and granular activated carbon-SBR (GAC-SBR) systems. Bioresource Technology 98 (14), 2749-2757.

Teng, H., Yeh, T.S., Hsu, L.Y., 1998. Preparation of activated carbon from bituminous coal with phosphoric acid activation. Carbon 36, 1387-1395.

Wang, C.K., 2004. Effects of carbonization conditions on the basic properties and adsorption ability of Taiwan giant bamboo and its carbonized material. A thesis of master degree of the Graduate Institute of Forestry, National Taiwan University, p. 115.

Weber, W.J., Mcginley, P.M., Katz, L.E., 1991. Sorption phenomena in subsurface system: concepts models and effects on contaminant fate and transport. Water Research 25, 499-528.

Wu, F.C., Tseng, R.L., Juang, R.S., 1999. Preparation of activated carbon from bamboo and their adsorption abilities for dyes and phenol. Journal of Environmental Science and Health 34 (9), 1753 1775 . 